\title{
Runoff generation in an intensively disturbed, abandoned farmland catchment, Central Spanish Pyrenees
}

\author{
J.M. García-Ruiz a , J. Arnáez b , S. Beguería a, M. Seeger a, c, \\ C. Martí-Bono a, D. Regüés a, N. Lana-Renault a and S. White d \\ a Instituto Pirenaico de Ecología, CSIC, Campus de Aula Dei, Apartado 202, 50080- \\ Zaragoza, Spain \\ b Dept. of Geography, University of La Rioja, 26004-Logroño, Spain. \\ c Physische Geographie. FB Geographie/Geowissenschaften, Universität Trier, D- \\ 54286 Trier, Germany. \\ d Institute of Water and Environment, Cranfield University, Silsoe, MK45 4DT, UK
}

\begin{abstract}
This paper studies the hydrological response to rainstorm events of a small experimental catchment in the Central Spanish Pyrenees. The Arnás catchment was cultivated until 40 years ago, and then abandoned and affected by plant recolonisation, especially shrubs. A rainfall of a few $\mathrm{mm}$ is enough to produce a sudden increase in discharge, due most probably to the steep gradients and the small size of the catchment and the extensive areas with low vegetation density and thin soils. The intensity of the response shows a very high variability, depending on the intensity of precipitation and soil humidity conditions before the flood. This paper identifies two types of floods according to the relationships between precipitation and discharge, and confirms that antecedent soil moisture explains much of the response. The shape of the hydrograph, very similar to the hyetograph, suggests that the Arnás catchment is dominated by overland flow processes. However, more intense rainstorms do not generate higher peak flows, thus demonstrating the existence of different runoff generating areas.
\end{abstract}

Keywords: Experimental catchment; Floods; Runoff contributing areas; Farmland abandonment; Central Spanish Pyrenees.

\section{Introduction}

Experimental catchments have been monitored worldwide (Walling, 1991) in order to i) understand the factors that control runoff generation and sediment transport processes (i.e. Tropeano, 1991; Seeger et al., in press), and ii) obtain detailed information on different parameters for hydrological modelling. Furthermore, the existence of experimental catchments with different plant cover and land use allows 
assessment of the influence of these factors on the long term evolution of water resources (Burch et al., 1987; Llorens and Gallart, 1992; Burney and Edwards, 1994; Ceballos and Schnabel, 1998), sediment yield (Erskine et al., 2002) and sediment budgets (Walling et al., 2002). This is especially true for those mountainous areas where large scale land use changes have occurred, or that are subject to increasing or decreasing population pressure. In the Spanish Pyrenees, for instance, population has decreased by $70 \%$ since the beginning of the 20th century. Likewise, most of the old farmed area, mainly located on steep slopes, has been abandoned and now is affected by plant colonisation processes (Molinillo et al., 1997). Such an evolution introduces changes in many hydrological parameters (Gallart et al., 1994; Beguería et al., 2003). This is especially important in Mediterranean environments, where mountains behave as "islands" of humidity in comparison with the plains, yielding most of the runoff drained by the rivers (Thornes, 1999).

This paper focuses on the relationships between precipitation and runoff in a small catchment in the Central Spanish Pyrenees (the Arnás catchment), which was cultivated until 40 years ago, and then abandoned. The analyisis of floods shows a highly variable response of discharge to rainfall. The main purpose of this paper is to identify different types of floods and to assess the factors explaining the variability of the hydrological response through the year, as well as to understand the hydrological functioning of a severely disturbed area.

\section{The study area}

The Arnás catchment is located in the Borau Valley, a tributary of the Aragón River, in the Central Spanish Pyrenees (Fig. 1). It has an area of 284 ha. The highest peak is at $1330 \mathrm{~m}$ a.s.1., and the outlet at about $900 \mathrm{~m}$ a.s.1. The bedrock corresponds to the Eocene flysch, with alternating thin layers of sandstones and marls.

The ravine runs from west to east, resulting in a strong contrast between the south and the north facing slopes, the former being much steeper. Both aspects show several debris flows as well as old scars and tongues belonging to deep mass movements (earth flows and slumps), nowadays inactive. Patches affected by severe sheet wash erosion are spread over the south facing slope, relatively close to the ravine. Many vegetation free trails can be found due to current grazing activity of sheep flocks.

Average annual precipitation is around $1000 \mathrm{~mm}$ in the lowest part of the catchment. No differences have been found with precipitation recorded in other places of the catchment. The rainy season mainly occurs in autumn and spring. Summer rainstorms are relatively frequent, though the most intense rainfalls tend to occur in October and November (García-Ruiz et al., 2000a). Snowfalls are relatively frequent 
from December to April, but it remains only a few days on the soil, since the $0^{\mathrm{a}} \mathrm{C}$ isotherm of the cold season is located over $1600 \mathrm{~m}$ a.s.l. (Beguería et al., 2003).

The Arnás catchment was totally cultivated until the middle of the 20th century with cereal cropping even on steep and convex slopes. Permanent bench terraced fields prevailed on the shady slopes and in the concave hillslopes of the sunny aspect. Sloping fields, cultivated during 2 or 3 years every 20 years under shifting agriculture systems, occupied the convex slopes of the sunny aspect. Since then the catchment was abandoned and affected by a process of natural plant colonisation with Genista scorpius, Buxus sempervirens and Rosa gr. canina on the south facing slope (covering $80 \%$ of the surface), whereas Echynospartum horridum dominates on the shady slope (100\% of the surface). The highest hillslopes have been partially colonised by Pinus sylvestris and Quercus faginea.

The soils of the south facing slope are mostly poorly developed and strongly eroded, shallow carbonate-rich Regosols, with Calcaric Cambisols over bench terraced fields on concave slopes. The north facing slope shows more developed soils with high enrichment of organic matter (Kastanozems). At the valley bottom stagnic conditions prevail (Stagnic Luvisols and Calcisols). The low infiltration capacity tends to decrease with soil depth (Seeger, 2001).

The flow is perennial, and only at the end of the summer (September) it can be reduced to nearly exhaustion. The average discharge is about $21.71 \mathrm{~s}^{-1}$.

\section{Equipment}

At the outlet of the Arnás ravine a concrete rectangular flume was built and an ultra-sound sensor (Lundhal DCU-7110) has been installed to measure the water stage. A calibration curve relates stage and discharge. The flume has a maximum capacity of $3 \mathrm{~m}^{3} \mathrm{~s}^{-1}$. The sensor is connected to a data logger. The water stage is collected every 5 seconds, recording the average every 5 minutes.

A weather station has been installed near to the gauging station, collecting continuous information on air temperature, air humidity, radiation, wind-speed and precipitation.

\section{Methods}

The information on stage and weather is downloaded every 15 days to a portable computer. Water stage is transformed into discharge $\left(\mathrm{l} \mathrm{s}^{-1}\right)$. Errors are corrected if their effect is minimal, or eliminated. Floods are identified as increases in discharge exceeding 1.5 times the base flow discharge prior to the beginning of the rainstorm event. The starting point of the flood is identified as a sudden, positive change in the discharge, and the end is established when the falling limb of the 
hydrograph remains almost stable. The study period includes the years 1996 (except November and December), 1997 (except March), 1999 (except some days of January, February and March), 2000 and 2001.

The total discharge of each flood is calculated $\left(\mathrm{m}^{3}\right)$, as well as the peak flow (1 $\left.\mathrm{s}^{-1}\right)$, the mean discharge $\left(1 \mathrm{~s}^{-1}\right)$, the duration of the flood (minutes), the base flow at the beginning of the flood $\left(1 \mathrm{~s}^{-1}\right)$, the average discharge 24 hours before the flood $\left(1 \mathrm{~s}^{-}\right.$ 1) and the percentage of direct runoff (storm flow, that is, the proportion of discharge directly fed by precipitation, discounting the base flow). The proportion of both the base flow and the direct flow has been calculated following the method of Hewlett and Hibbert (1967).

Information on precipitation enables us to obtain, for each rainstorm event, the duration of precipitation (minutes), total precipitation $(\mathrm{mm})$, the rainfall intensity in 5 and 30 minutes $(\mathrm{mm})$ and the precipitation recorded 1,3 and 7 days before any flood $(\mathrm{mm})$.

Once the basic information on precipitation and discharge is available, it is possible to derive other important variables, i.e., the runoff coefficient and the lag between precipitation and discharge (that is, the difference in minutes between the centroid of the rainstorm event and the peak flow). Thus, a data base has been constructed, including a total of 103 floods considered and 17 variables for each flood.

The statistical analysis consisted of three steps: 1) Descriptive statistics for the description of the floods (means and frequency distribution of the floods); 2) Multivariate statistics (Cluster and ANOVA) in order to assess the differences between floods; 3) Stepwise multiple regressions to test the weight of the different variables on runoff generation. The Spearman's Rho correlation statistic against time has been used to test possible temporal trends in the hydrological response of the catchment.

\section{Results}

A total of 103 floods have been identified during the study period in the Arnás catchment. The maximum value of a rainstorm event was $63.2 \mathrm{~mm}$, and the minimum $4 \mathrm{~mm}$. Most of the rainstorm events were of small magnitude (49 in total were lower than $15 \mathrm{~mm}$, and only 5 were greater than $45 \mathrm{~mm}$ ). The highest peakflow reached $2726.4 \mathrm{~s}^{-1}$ (2.8 years return period), and the lowest $40.51 \mathrm{~s} \mathrm{~s}^{-1}$ (16.4 days return period). Most of the floods (66.6\%) had peaks below $500 \mathrm{l} \mathrm{s}^{-1}$ whereas 10 (9.5\%) surpassed $15001 \mathrm{~s}^{-1}$.

Fig. 2 shows 4 examples of flood hydrographs in the Arnás catchment, with their corresponding rainfall distribution. They serve to demonstrate i) the variability 
of hydrographs, very simple in some cases or with a complex pattern in others; and ii) the sudden increase of the discharge as a response to precipitation, with a fast rising limb of the hydrograph. The falling limb also decreases very quickly, showing a rapid exhaustion of the catchment once the precipitation has ceased. Furthermore, the hydrograph tends to roughly reproduce the shape of the rainstorm event. This is clearly the case of Fig. 2A (21st September, 2000), with an increase in discharge following an increase of the rainstorm intensity, and a decrease in discharge briefly interrupted by a small peak related to another increase in rainfall intensity. Fig. 2B (2nd December 2000) shows two periods of rainfall and two corresponding peakflows, the second one higher than the first, due most probably to soil saturation. Fig. 2C (10th November, 1997) also shows an irregular rainstorm event, resulting in a fluctuating hydrograph that repeats the rainfall intensity. As in the case of Fig. 2B, the hydrograph shows waves of increasing discharge. Finally, Fig. 2D (22nd December, 2000) corresponds to a two-peak intense rainfall, that causes a hydrograph with two peakflows.

The rest of the floods considered also show this clear dependence on the shape of the rainstorm. However, the relationship between total precipitation and peakflow is not so obvious $\left(r^{2}=.44\right)$. Fig. 3 shows that most of the points are scattered away from the regression line, suggesting that the intensity of the hydrological response is also controlled by other important factors. In fact, for similar precipitation events the resulting peakflow can reach very different values. In other words, there is an increase in the peak flow as precipitation increases, but the variability is so great that it hides the trend. The problem is why the relationships between precipitation and peak flow are so poor and how is it possible to explain them by using the information on precipitation and discharge available at the outlet of the catchment. One possibility is the cluster analysis, which enables the identification of different types of floods and an analysis of variance (ANOVA) to find the most significant differences between groups.

As a way to capture the interaction between rainfall and runoff peak, a new variate was constructed as the quotient of both variables. A cluster analysis was then performed upon this variate, resulting in a division of the data set in two different groups (Fig. 4). The two groups of floods are shown in Fig. 5, along with their corresponding regression lines. One of the groups (G1) represents a rapid hydrological response to any precipitation, with a flashy increase of the peak flow. The other group (G2) includes the floods with a slower response, characterized by a small increase in discharge even if the precipitation is very high. The rate of increase of the peak flow in relation to total precipitation is clearly higher in G1 than in G2. This separation into two groups increases the coefficient of determination of the 
regressions: $\mathrm{r}^{2}=.77$ for $\mathrm{G} 1$ and $\mathrm{r}^{2}=.66$ for $\mathrm{G} 2$. The slope of the regression lines is 44.3 and 19.7, respectively, showing the different response of flow to precipitation.

The following steps have been to characterize both groups according to mean values and to perform an Analysis of Variance to assess the significance of the differences (Table 1). Three groups of variables contribute to explain the differences between the two groups:

i) The intensity of precipitation, clearly higher in G1 $(2.35 \mathrm{~mm}$ in $5 \mathrm{~min} ; 6.19$ $\mathrm{mm}$ in $30 \mathrm{~min}$ ) than in $\mathrm{G} 2(1.4 \mathrm{~mm}$ in $5 \mathrm{~min} ; 3.9 \mathrm{~mm}$ in $30 \mathrm{~min})$. Total precipitation during each rainstorm event has a lower significance, but still gives higher values in G1 $(24.3 \mathrm{~mm})$ than in $\mathrm{G} 2(17.7 \mathrm{~mm})$.

ii) Some features of the antecedent discharge, for instance the discharge 24 hours before the beginning of the rainfall (140.5 $1 \mathrm{~s}^{-1}$ in G1; $74.91 \mathrm{~s}^{-1}$ in G2), and the base flow at the beginning of the event $\left(67.11 \mathrm{~s}^{-1}\right.$ in $\mathrm{G} 1 ; 36.91 \mathrm{~s}^{-1}$ in G2).

iii) The main features of the discharge during the flood. Thus, the greatest differences between the groups correspond to the peak flow (1407 1 s ${ }^{-1}$ in G1; 297.21 $\mathrm{s}^{-1}$ in $\left.\mathrm{G} 2\right)$, as well as to the runoff coefficient (0.33 in G1; 0.14 in G2). The percentage of base flow during the flood is also significantly different: $18 \%$ in G1 and $42.9 \%$ in $\mathrm{G} 2$.

The time of occurrence of every flood, starting in January 1996, was also included in the ANOVA. This temporal variable did not show significant differences between the two groups. This means that the discrimination between both groups is not related to the evolution of runoff due to possible changes in plant cover or precipitation. A possible change in the catchment response during the study period must be also rejected since the runoff coefficient during floods does not show a significant trend (Spearman's Rho, $\mathrm{p}=.850$ ).

A stepwise regression analysis was performed to determine the variables that control the magnitude of the peak flow for each group. These results are shown in Table 2 . The regression for group $1\left(\mathrm{r}^{2}=.735\right)$ included only the total precipitation. Precipitation is also the most determinant factor to explain the peak flow for group 2 $\left(\mathrm{r}^{2}=.746\right)$, but the precipitation of the three days preceding the flood was also included in the equation.

A classification of floods into two groups according to the season (wet season, from November to May; dry season, from June to October) provides rather poor coefficients of determination for the regressions between total rainfall and peak flow. In the case of the wet season floods (Fig. 6), a clear increasing trend as rainfall increases has been obtained, though the variability around the regression line is very high $\left(r^{2}=.46\right)$. For the dry season floods (Fig. 7) the increasing trend also exists, but the scattering of points is even greater $\left(r^{2}=.42\right)$. Four of these points are located far 
away over the regression line, all related to heavy summer rainstorms, with an intensity of precipitation twice the average (9.6 vs $5.4 \mathrm{~mm} \mathrm{hr}-1)$. In both cases (wet and dry season) a number of events are characterized by very low peak flows, even if the rainstorm event reaches almost $30 \mathrm{~mm}$. New regressions between the residuals from Fig. 5 and 6 and other variables (intensity of rainfall, precipitation one day before the flood, base flow at the beginning of the flood) do not provide any significant improvement (with $\mathrm{r}^{2}$ around 0.1).

Significant differences between wet and dry season floods (Table 3) have been found in total rainfall and the intensity of rainfall, with values always higher in the dry season floods. The conditions prior to the flood are higher in the wet season floods (i.e., the base flow at the beginning of the flood, and the discharge 24 hours before), as well as the runoff coefficient, and the total volume of discharge during the flood. That is, the inputs are, in general, higher during the dry season floods, whereas the outputs are higher during the wet season floods.

\section{Discussion and conclusions}

The Arnás catchment reacts to almost any rainstorm event (Arnáez et al., 1999), but the response shows a very high variability. In general, a rainfall of a few $\mathrm{mm}$ is enough to produce a sudden increase in the hydrograph, due most probably to the steep gradients and the small size of the catchment, as well as to the existence of eroded areas close to the main channel, inherited from past farming activities and overgrazing. However, the intensity of the response depends on many circumstances. In fact, considering all the floods, the relationship between rainfall and peak flow is relatively low, with many points scattered away from the regression line. This means that, for instance, a rainstorm event of around $50 \mathrm{~mm}$ can generate a flood of more than $25001 \mathrm{~s}^{-1}$, or a flood of less than $10001 \mathrm{~s}^{-1}$. In other words, a rainstorm event of $30 \mathrm{~mm}$ can produce a discharge higher than that caused by a rainstorm event of more than $60 \mathrm{~mm}$. This variability has been also found in other catchments under different Mediterranean environments: the Guadalperalón catchment under dehesa land use (Ceballos and Schnabel, 1998; Ceballos, 1999; Schnabel and Mateos, 2000), the Vallcebre catchment with abandoned, reforested bench terraced fields (Llorens and Gallart, 1992), and the Sierra de Picarcho catchments, SE Spain, with an open shrub cover (Castillo et al., 2000).

A purely statistical analysis has demonstrated that the hydrological response in the Arnás catchment can be splitted in two different ways, in such a manner that two different regression lines can be drawn (Fig. 4). One line represents those runoff events related with higher intensity of precipitation (6.19 vs $3.9 \mathrm{~mm}$ in $30 \mathrm{~min})$ and higher total rainfall (24.3 vs $17.7 \mathrm{~mm}$ ), as well as wetter conditions before the flood 
(67.1 vs $36.91 \mathrm{~s}^{-1}$ as base flow). As a consequence, the hydrological response is faster and the peak flow is much higher (1407 vs $297 \mathrm{l} \mathrm{s}^{-1}$ in the peak flow). The contribution of base flow to the peak flow is relatively low, with the direct runoff dominating stream response. This group of floods produces a steep regression line, confirming that peak flows are clearly higher as the value of rainfall increases.

The other line is characterized by a lower gradient, in such a manner that an increase in rainfall produces a small increase in peak flow.

Although that classification is not related to any seasonality, differences have also been found between wet and dry season floods (García-Ruiz et al., 2000b). The most important difference is that the input factors (rainfall, intensity of precipitation) are higher during the dry season, whereas most of the outputs (runoff coefficient and total volume of discharge during the flood) are higher during the wet season floods. The antecedent conditions of the catchment (indirectly deduced from the discharge prior to the flood and the base flow) are also higher in the wet season floods.

All these results suggest that, if precipitation is an important factor to explain the shape and height of the hydrograph, the antecedent soil moisture contributes very much to explain the intensity of the response, and relatively high discharges 24 hours before the beginning of the flood are a good predictor of the intensity of the peak flow. In fact, the base flow before the flood is an excellent surrogate for antecedent soil humidity. These conditions are expected to be more frequent during the wet season. During the dry season the intensity of precipitation and even the rainfall recorded can be higher than during the wet season, but the peak flow is not necessarily also higher.

Nevertheless, no clear coincidence exists between both flood classifications, since during the wet season dry periods are possible, and some floods can behave as they would belong to the dry season. More exceptionally, some dry season floods can occur after several days of rainfall and their behaviour is similar to those occurring during the wet season.

The shape of the hydrograph (Fig. 2), very similar to the hyetograph, suggests that the Arnás catchment is dominated by overland flow or fast throughflow processes. Nevertheless, the results obtained demonstrate that it does not necessarily behave as a typical Hortonian pattern. In fact, more intense rainstorms do not generate higher peak flows. Probably, part of the areas located close to the channel and in the lowest hillslopes have a fast hydrological response, and this is the reason why the suspended sediment peak precedes the peak flow in most of the floods (Lorente et al., 2000). But the rest of the catchment, with greater density in plant cover (mainly shrubs after farmland abandonment) needs to have wet conditions to react against any 
precipitation, as has also been demonstrated in the dehesa environment (Schnabel and Mateos, 2000). This would be the reason for the occurrence of two types of floods:

i) Under dry conditions, a fast though limited hydrological response occurs, even during important rainstorm events, thus suggesting that overland flow is generated in a small part of the basin, close to the channel. For this reason, the peak of suspended sediment in the Arnás catchment tends to preced the peak flow under dry conditions (clockwise hysteretic loops) (Seeger et al., in press).

ii) Under wet conditions, the response is also fast, but the peak flow is much higher, even during moderate rainstorm events. This suggests an enlargement of the runoff generating areas, as it has been described by other authors (i.e. Dunne and Black, 1970; Gallart et al., 2002).

The validation of these interpretations would require a distribued monitoring of the soil hydrological conditions within the catchment.

\section{Acknowledgements}

This paper has been supported by the following projects: "Water resources management in a changing environment: the impact of sediment on sustainability" (WARMICE, ENV4-CT98-0789) funded by the European Comission, and "Assessment of sediment sources and runoff generation areas in relation to land use changes" (HIDROESCALA, REN2000-1709-C04-01/GLO), "Hydrological processes in semi-natural Mediterranean areas" (PROHISEM, REN 2001-2268-C02-01/HID), and "Hydrological processes in Pyrenean catchments in relation to land use and climate changes" (REN2003-08678/HID), all funded by CICYT. Monitoring of the catchment has been supported by the agreement between CSIC and the Spanish Ministry of Environment (RESEL).

\section{References}

Arnáez, J., Martí-Bono, C., Beguería, S., Lorente, A., Errea, M.P., García-Ruiz, J.M., 1999. Factores en la generación de crecidas en una cuenca de campos abandonados, Pirineo Central español. Cuadernos de Investigación Geográfica 25, 7-24.

Beguería, S., López-Moreno, J.I., Lorente, A., Seeger, M., García-Ruiz, J.M., 2003. Assessing the effect of climate oscillations and land-use changes on streamflow in the Central Spanish Pyrenees. Ambio, 32, 283-286.

Burch, G.J., Bath, R.K., Moore, I.D., O’Loughlin, J.M., 1987. Comparative hydrological behaviour of forested and cleared catchments in southeastern Australia. J. Hydrol. 90, 19-42. 
Burney, J.R., Edwards, L.M., 1994. Facilities for continuous monitoring of soil erosion in warm and cool seasons in Prince Edward Island, Canada. I. Watersheds. Catena 21, 329-340.

Castillo, V., Gómez-Plaza, A., Martínez-Mena, M., Albaladejo, J., 2000. Respuesta hidrológica en medios semiáridos: las cuencas experimentales de la Sierra del Picarcho, Murcia (España). Cuadernos de Investigación Geográfica 26, 81-94.

Ceballos, A., 1999. Procesos hidrológicos en una pequeña cuenca hidrográfica bajo explotación de dehesa en Extremadura. Universidad de Extremadura, Cáceres.

Ceballos, A., Schnabel, S., 1998. Hydrological behaviour of a small catchment in the dehesa landuse system (Extremadura, SW Spain). J. of Hydrol. 210, 146-160.

Dunne, T., and Black, R.D., 1970. An experimental investigation of runoff production in permeable soils. Water Resources Research 6(2): 478-490.

Erskine, W.D., Mahmoudzadeh, A., Myers, C., 2002. Land use effects on sediment yields and soil loss rates in small basins of Triassic sandstone near Sydney, NSW, Australia. Catena 49, 271-287.

Gallart, F., Llorens, P., Latron, J. and Regüés, D., 2002. Hydrological processes and their seasonal controls in a small Mediterranean mountain catchment in the Pyrenees. Hydrology and Earth System Sciences, 6:527-537.

Gallart, F., Llorens, P., Latron, J., 1994. Studying the role of old agricultural terraces on runoff generation in a small Mediterranean mountainous basin. J. Hydrol. 159, 291-303.

García-Ruiz, J.M., Arnáez, J., White, S., Lorente, A., Beguería, S., 2000a. Uncertainty assessment in the prediction of extreme rainfall events; an example from the Central Spanish Pyrenees. Hydrol. Proc. 14, 887-898.

García-Ruiz, J.M., Martí-Bono, C., Arnáez, J., Beguería, S., Lorente, A., Seeger, M., 2000b. Las cuencas experimentales de Arnás y San Salvador en el Pirineo Central español: escorrentía y transporte de sedimento. Cuadernos de Investigación Geográfica 26, 23-40.

Hewlett, J.D., Hibbert, A.R., 1967. Factors affecting the response of small watersheds to precipitation in humid regions. In: W.E. Sopper and H. W. Lull (Eds.), Forest hydrology, Pergamon Press, Oxford, pp. 275-290.

Llorens, P., Gallart, F., 1992. Small basin response in a Mediterranean mountainous abandoned farming area. Research design and preliminary results. Catena 19, 309320.

Lorente, A., Martí-Bono, C., Beguería, S., Arnáez, J., García-Ruiz, J.M., 2000. La exportación de sedimento en suspensión en una cuenca de campos abandonados, Pirineo Central español. Cuaternario y Geomorfología 14, 21-34. 
Molinillo, M., Lasanta, T., García-Ruiz, J.M., 1997. Managing mountainous degraded landscapes after farmland abandonment in the Central Spanish Pyrenees. Environmental Management 21, 587-598.

Schnabel, S., Mateos, B., 2000. Hidrología superficial en ambientes adehesados, cuenca experimental Guadalperalón. Cuadernos de Investigación Geográfica 26, 113-130.

Seeger, M., 2001. Boden und Bodenwasserhaushalt als Indikatoren der Landdegradierung auf extensiviertenj Nutzflächen in Aragón, Spanien. Freiburger Geographische Hefte 63, 1-184.

Seeger, M., Errea, M.P., Beguería, S., Arnáez, J., Martí, C., García-Ruiz, J.M., in press. Catchment soil moisture and rainfall characteristics as determinant factors for discharge/suspended sediment hysteretic loops in a small headwater catchment in the Spanish Pyrenees. J. Hydrol.

Thornes, J., 1999. The hydrological cycle and the role of water in Mediterranean environments. In: F.B. Golley \& J. Bellot (Eds.), Rural planning from an environmental systems perspective, Springer, Ijmuiden, pp. 85-107.

Tropeano, D., 1991. High flow events and sediment transport in small streams of the 'Tertiary Basin' area in Piedmont (Northwest Italy). Earth Surf. Proc. Landf. 16, 323-319.

Walling, D.E., 1991. Drainage basin studies. In: O. Slaymaker (Ed.) Field experiments and measurement programs in Geomorphology, Balkema, Rotterdam, pp. 17-59.

Walling, D,E., Russell, M.A., Hodgkinson, R.A., Zhang, Y., 2002. Establishing sediment budgets for two small lowland agricultural catchments in the UK. Catena 47, 323-353. 


\section{FIGURE CAPTIONS}

Fig. 1. The study area.

Fig. 2. Examples of rainfall and streamflow for selected storms in the Arnás catchments.

Fig. 3. Relationships between peak flow and precipitation.

Fig. 4. Dendrogram from cluster analysis on peak flow/precipitation.

Fig. 5. Relationships between peak flow and precipitation, distinguishing two groups of floods.

Fig. 6. Relationships between peak flow and precipitation for the wet season floods.

Fig. 7. Relationships between peak flow and precipitation for the dry season floods. 


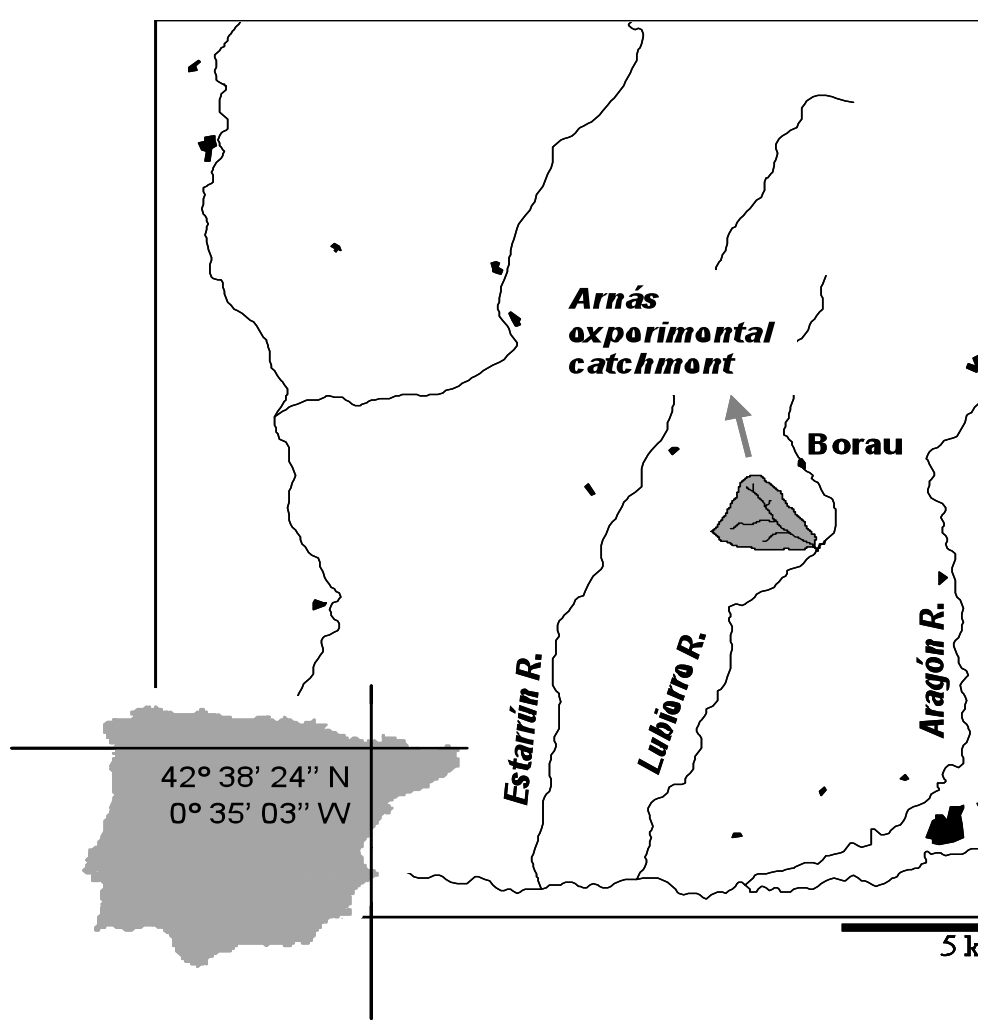

Fig. 1 

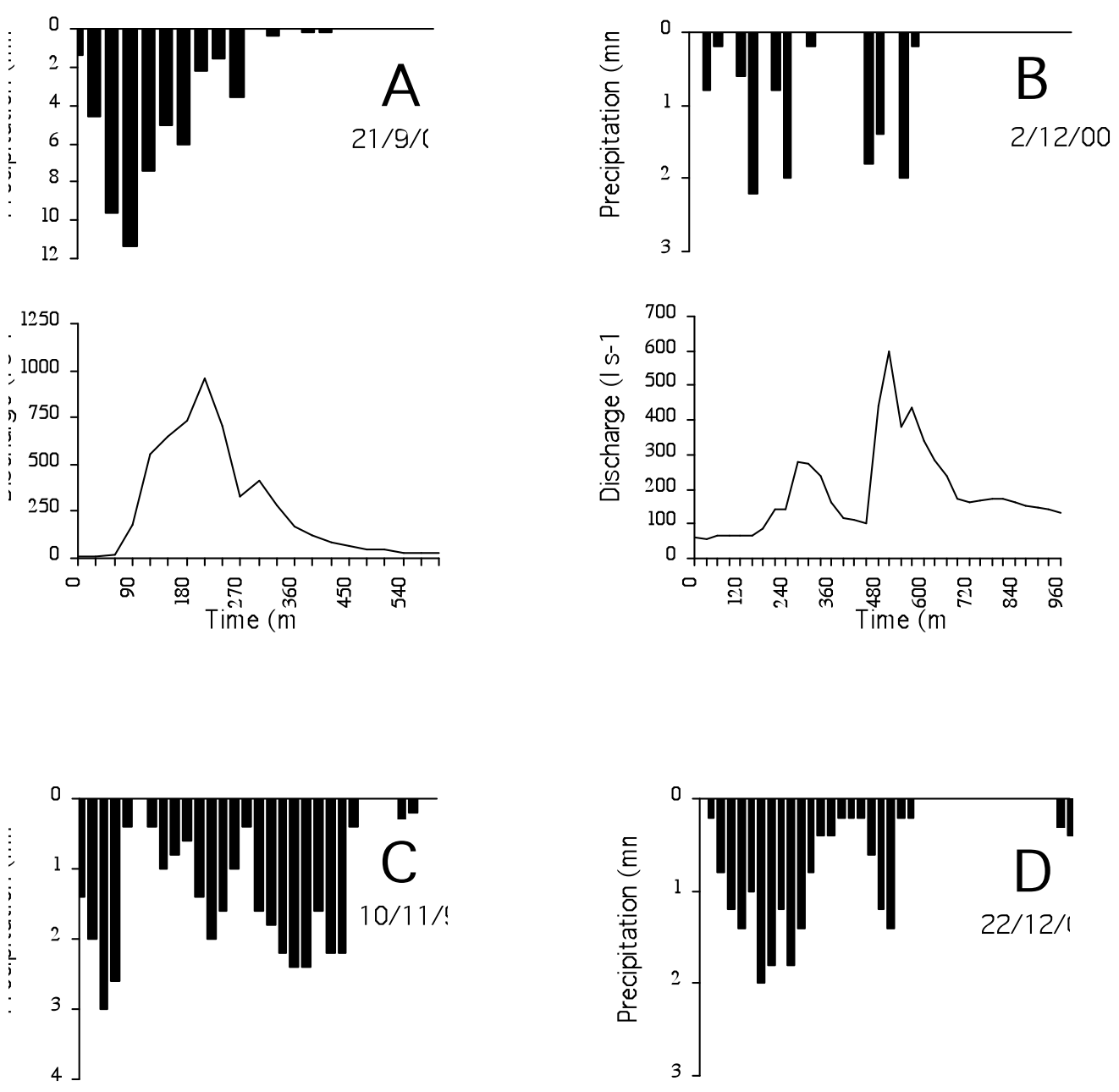

Fig. 2 


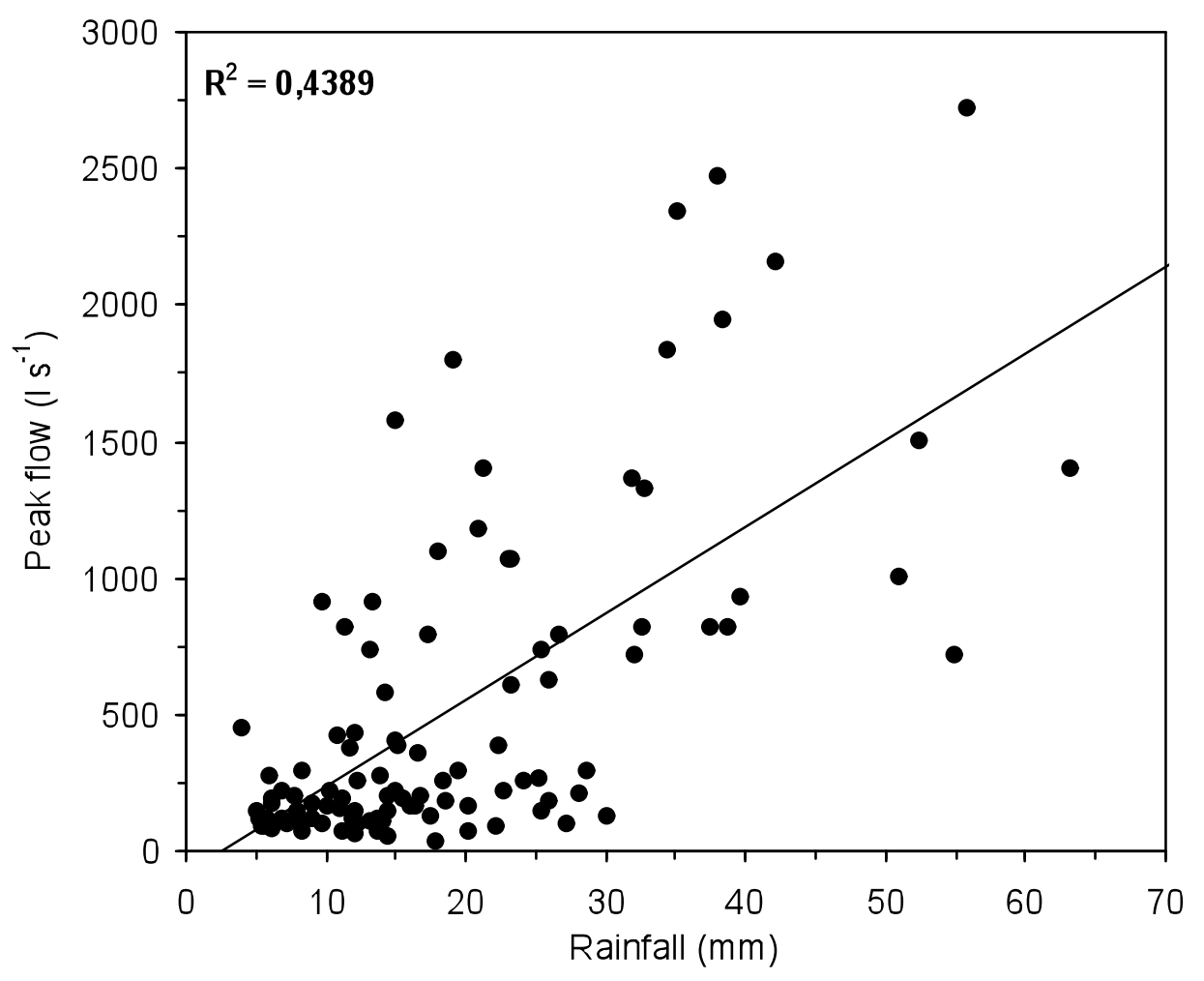

FIG. 3 

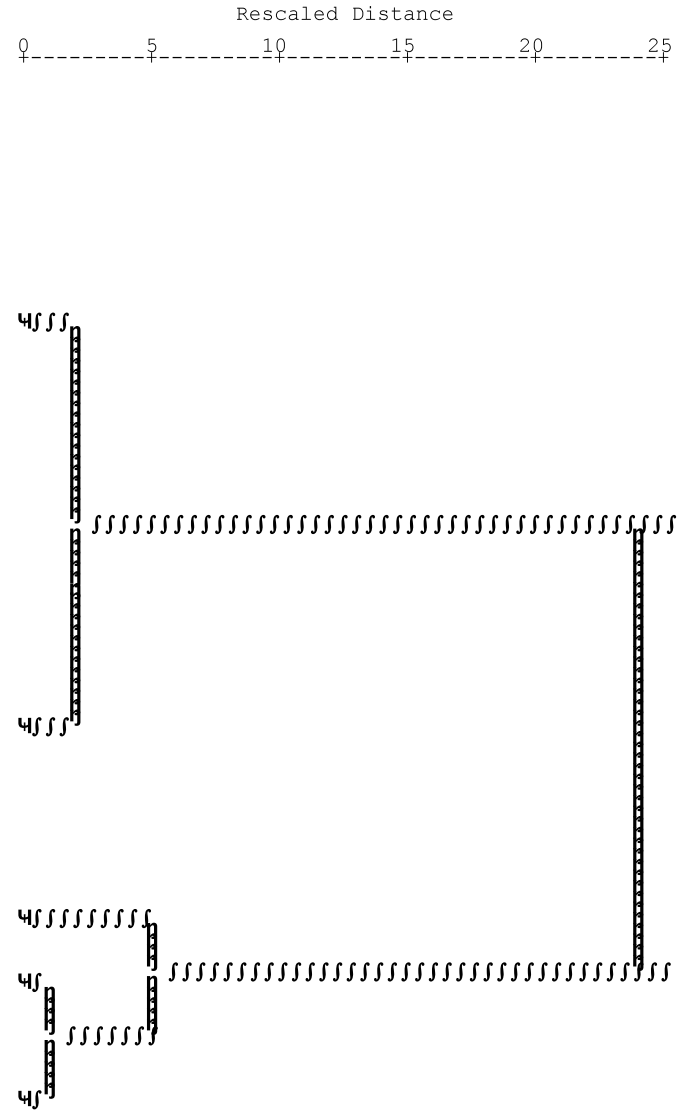

FIG. 4 


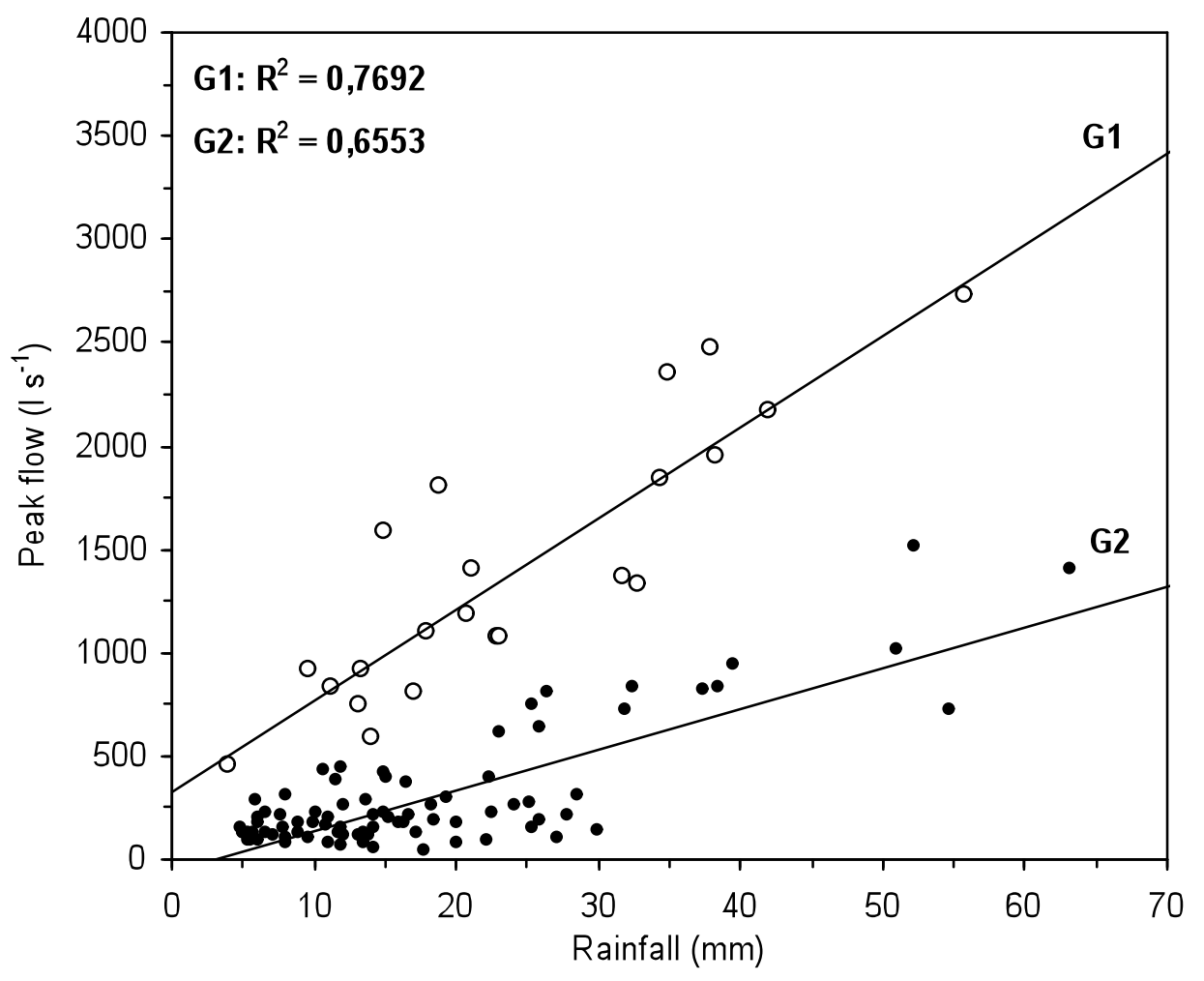

FIG. 5 


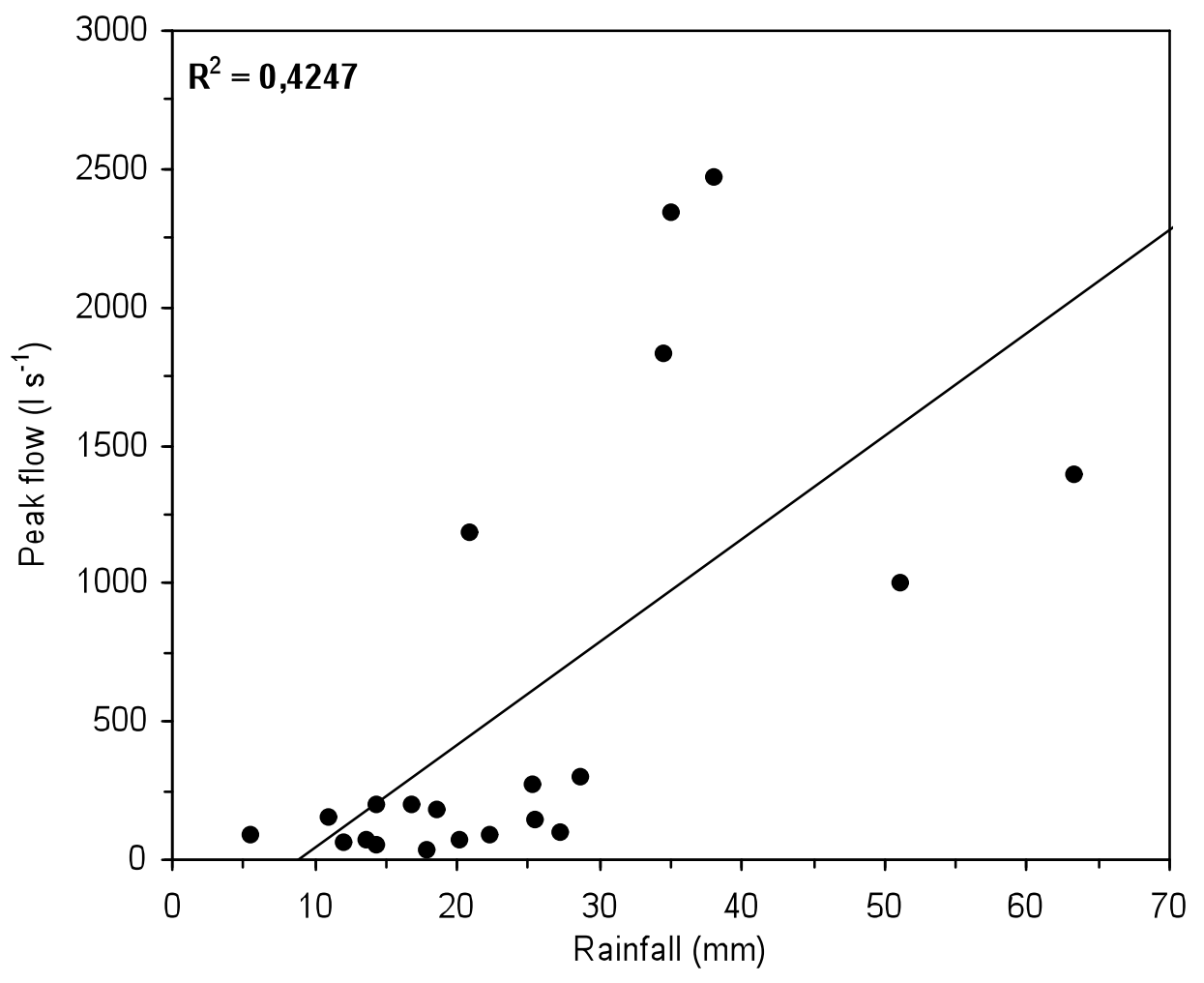

FIG. 6 


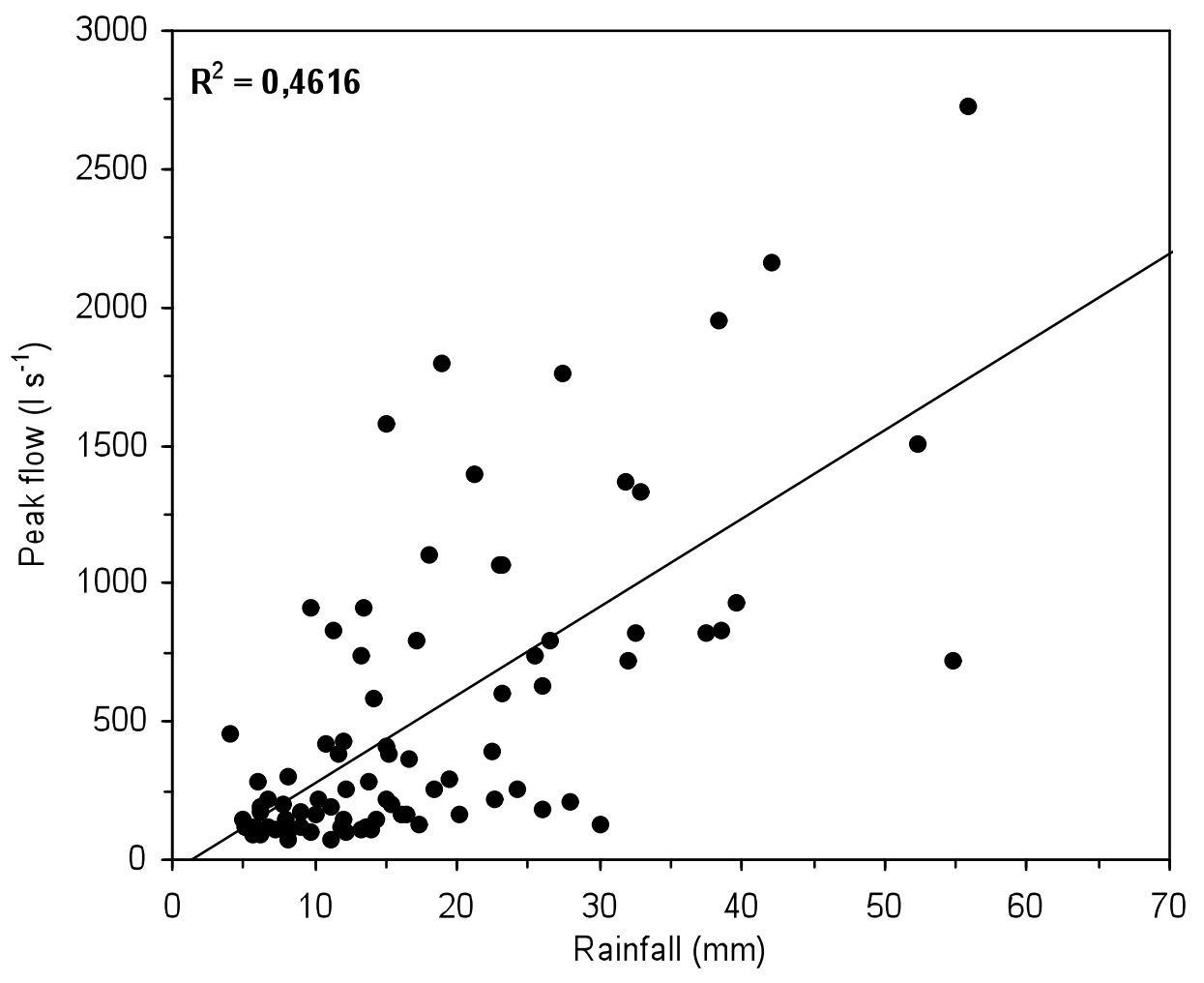

Fig. 7 
Table 1. Average values and ANOVA for variables of G1 and G2 floods

\begin{tabular}{|c|c|c|c|}
\hline Variable & G1 & G2 & $p$ \\
\hline Precipitation $(\mathrm{mm})$ & 24.31 & 17.73 & $.0238^{*}$ \\
\hline Peak flow $\left(1 \mathrm{sg}^{-1}\right)$ & 1406.96 & 297.17 & $.0001^{*}$ \\
\hline Intens. P 5 min. & 2.35 & 1.38 & $.0186^{*}$ \\
\hline Intens. P $30 \mathrm{~min}$. & 6.19 & 3.91 & $.0133^{*}$ \\
\hline P 1 day before $(\mathrm{mm})$ & 16.89 & 11.9 & .1706 \\
\hline P 3 days before $(\mathrm{mm})$ & 29.40 & 24.33 & .3388 \\
\hline Initial Baseflow $\left(1 \mathrm{sg}^{-1}\right)$ & 67.11 & 36.85 & $.0005^{*}$ \\
\hline Rainfall time (min.) & 390 & 347 & .4225 \\
\hline Flood time (min.) & 653 & 647 & .9427 \\
\hline Runoff coeff. & .33 & .14 & $.0001 *$ \\
\hline Total discharge $\left(\mathrm{m}^{3}\right)$ & 23428.60 & 12932.21 & $.0256^{*}$ \\
\hline$\%$ Base flow & 17.98 & 42.94 & $.0001^{*}$ \\
\hline Disch. 24 hr. before $\left(1 \mathrm{sg}^{-1}\right)$ & 140.48 & 74.91 & $.0254 *$ \\
\hline Lag P / Peak flow (min.) & 139 & 149 & .7160 \\
\hline Time (months since Jan 1996) & 42.55 & 36.63 & .2098 \\
\hline $\mathrm{N}^{\mathrm{o}}$ cases & 23 & 82 & \\
\hline Wet season & 19 & $\begin{array}{l}65 \\
17\end{array}$ & \\
\hline & 4 & 17 & \\
\hline
\end{tabular}

* Significance level 95\% 
Table 2. Stepwise regression: Standardized Beta coefficients (B) and significance level $(p)$.

\section{Dependent variable: Peak flow}

\begin{tabular}{lcccc} 
& \multicolumn{2}{c}{$\mathrm{G} 1$} & \multicolumn{2}{c}{$\mathrm{G} 2$} \\
\cline { 2 - 5 } Precipitation (mm) & $\mathrm{B}$ & $p$ & $\mathrm{~B}$ & $p$ \\
Intens. P 5 min. & 857 & $<0.001$ & .795 & $<0.001$ \\
Intens. P 30 min. & - & .303 & - & .054 \\
P 1 day before (mm) & - & .238 & - & .196 \\
P 3 days before (mm) & - & .775 & - & .626 \\
Disch. 24 hr. before $\left(1 \mathrm{~s}^{-1}\right)$ & - & .440 & .265 & $<0.001$ \\
Initial Baseflow $\left(\mathrm{l} \mathrm{sg}^{-1}\right)$ & - & .708 & - & .055 \\
& - & .155 & - & .204
\end{tabular}


Table 3. Average values and ANOVA distinguishing between wet and dry season floods

\begin{tabular}{|l|c|c|c|}
\hline \multicolumn{1}{|c|}{ Variable } & Wet season & Dry season & p \\
\hline Precipitation (mm) & 17.83 & 25.53 & $.0260^{*}$ \\
\hline Peak flow (1 s $\left.{ }^{-1}\right)$ & 526.03 & 584.49 & .6886 \\
\hline Intens. P 5 min. & 1.20 & 3.18 & $.0001^{*}$ \\
\hline Intens. P 30 min. & 3.50 & 8.07 & $.0001^{*}$ \\
\hline P 1 day before (mm) & 12.67 & 14.11 & .6981 \\
\hline P 3 days before (mm) & 27.42 & 18.18 & .0850 \\
\hline Initial Baseflow (1 s-1) & 48.29 & 24.22 & $.0078^{*}$ \\
\hline Rainfall duration (min.) & 386 & 240 & $.0067^{*}$ \\
\hline Flood duration (min.) & 688 & 490 & $.0088^{*}$ \\
\hline Runoff coeff. & .20 & .09 & $.0080^{*}$ \\
\hline Total discharge (m $\left.{ }^{3}\right)$ & 17021.81 & 5715.27 & $.0279^{*}$ \\
\hline \% Base flow & 38.48 & 33.45 & .3660 \\
\hline Disch. 24 hr. before (1 s $\left.{ }^{-1}\right)$ & 98.90 & 49.94 & .1028 \\
\hline Lag P / Peak flow (min.) & 153.3 & 121.4 & .2414 \\
\hline No cases & 84 & 21 & \\
\hline$*$ Significance level 95\% & & & \\
\hline
\end{tabular}

* Significance level $95 \%$ 